\title{
ROLE OF ISLAMIC ETHICS TOWARDS ETHICAL ACCOUNTING PRACTICE
}

\author{
Ika Sari Wahyuni -TD ${ }^{1,}$, Y Yudi Fernando2 and Evi Hasnita ${ }^{3}$ \\ ${ }^{1}$ Faculty of Industrial Management, Universiti Malaysia Pahang, Malaysia \\ ${ }^{2}$ Governance and Integrity Centre, Faculty of Industrial Management, Universiti Malaysia Pahang, Malaysia \\ 3STikes Fort De Kock,, Indonesia
}

ABSTRACT - The objective of this paper is to understand the role of Islamic ethics and its application towards a more ethical accounting practice. This paper has reviewed the literature on Islamic ethics and ethical accounting practice and found that four critical domains of Islamic ethics such as 1) accounting education; 2) principle of Islamic ethics; 3) code of ethics for accountants and 4) application of Islamic ethics for accountants. This study concludes that an Islamic guideline for accountants is a driver of ethical behaviour to comply with Islamic principles. It is highly needed in current turbulence business environment and competitors' pressure. The Muslim accountant can use Islamic ethics as a reference to ensure the excellent audit work to comply with Shari'ah requirements and to provide the required information demanded by society such as by doing khayr (goodness), birr (righteousness), 'adl (equilibrium and justice), trust (Amanah), benevolence (Ihsaan) and others. The understanding and application of Islamic ethics contribute towards a more ethical accounting practice.
ARTICLE HISTORY

Received: 09-08-2018

Accepted: $16-10-2018$

\section{KEYWORDS}

Islamic ethics, Ethical accounting, Integrity, Auditor, Shari'ah principles

\section{INTRODUCTION}

Ethics is commonly known as a set of moral principles that concern with the nature of value by which human beings can distinguish their actions in what is right from what is wrong. The term of ethics is assumed as the normative field due to it only prescribes about what should be do in life and what is abstain from doing (Carroll, 1998). The meaning of normative values here is that the definition to do a good or a bad and right or wrong is only contemporary in nature whereby good or bad can be different between one people to another people, between one country to another country. In this point, the nature of ethics is very tentative, it may be good for someone and it may be bad for others. On the contrary, in Islam to become ethically is not following "as long as society accepts", since being ethical is clearly not a matter of following the others' beliefs. In fact, it can definitely deviate from what does define as being ethical based on religion beliefs. In Islam, whatever the Muslims do, they must follow the Islamic requirements and it should only imply one's relationship with God (Al-Tawhid) by doing total submission that is enacted willingly as absolute obedience to the law revealed by Allah (Al-Faruqi, 1986; Al-Attas, 1978). Thus, ethics that defines by religion is the absolute in nature, Islam is a religion that can set high ethical standards and can provide intense motivations for ethical behaviour in all aspects of human life including accounting. Indeed, the position of accountants is involved with humanity problem that facing sophisticated a moral dilemma when they dealing in preparing and communicating the financial information. The role of an Islamic ethics is very important for accountants to conduct their duty in professionally as well as ethically. Thus, it is hoped that the understanding and application of Islamic ethics by accountants can contribute towards a more ethical accounting practice.

Therefore, the fundamental question addressed in this paper is to discuss the role of Islamic ethics, whether it is reasonable that religious ethics have an impact on the manner in which financial reports are presented as well as how can the understanding and application of Islamic ethics contribute towards a more ethical accounting practice. In addressing this matter, the next section of this paper is organized as follows. The section two presents an overview of education and accounting in current practice. Next, the justification of the importance of Islamic ethics is discussed in the third section. In the fourth section, AAOIFI's code of ethics for accountants is discussed. Next, the understanding and application of Islamic ethics for accountants is also presented. Finally, the conclusion is presented in the last section.

\section{LITERATURE REVIEW}

\section{Education and Accounting in Current Practice}

There is a growing need of education as an instrument to acquire continues knowledge through certain institutionalized organs of society such as schools, universities and others. Accountants need to possess knowledge and skills relating to scientific knowledge, moral values and ethics (Mayper et al., 2000). Measuring historical and qualitative factors may indicate accounting students' performance or it is called as accumulated knowledge (Alanzi et al., 2017). Yet, students' performance is no less important if it does not meet with a set of moral value. The last seventeen years, accounting 
profession has reached dramatic fraud scandal; Enron's collapse is much due to the low moral standards of accountants. Many scholars argued that, one of the reasons behind this is because the current accounting education system does not address the ethical curriculum which attempts to develop a sense of moral sympathy for others (McPhail, 2001; Carroll, 1998; Abdul Rahman, 2003). In addition, Abdul Rahman (2003) pointed out that as a part of accounting education process, it is very essential to teach moral value and ethics rather than only focus on accounting technique.

Further, Mayper et al. (2000) examined accounting and non-accounting students' perception to view accounting issues as containing a moral dimension by providing the capital budgeting scenario (financial factor and labour cost savings). Surprisingly, the results showed that majority of accounting students view the financial factor and labour cost savings only as economic issue rather than a moral issue. However, this is slightly different for non-accounting students who perceive the labour cost savings as both economic and moral issues factor. This is because most of non-accounting students tended to view the environmental factor as a moral issue. In this turn, still accounting does not recognize by students as a moral content, but the perceptions are definitely economic dominated. As anticipated by Carroll (1998), education in ethical and professional responsibilities is very important in the context of professional accounting. It means education for develop a framework to provide an ethics education as a basis for students to be more logically in thinking, critically in analysis and inquiry the accounting issues.

In addition, the rapid spread of technology has led enormous development of business acceleration. These changes have affected the way of people in doing business transaction which is become more complex and diverse. These business model expansions have changed extremely the way of business transactions being dealings in worldwide and new challenges to education. As a consequence, accounting students should be professional to present and communicate the financial report. Accounting data has to be reliable in order to help the users of financial accounting information in administrative decision-making process (Akyel, 2012). They are progressively requesting a presentation of financial information is free from frauds. Thus, corporation of accounting knowledge and ethics as moral philosophy have required a set of high values of accounting reporting.

\section{The Importance of Islamic Ethics}

In Islamic context, Muslims derive the ethics from two primary sources which is the Qur'an and the Sunnah of the Prophet Muhammad (p.b.u.h). Ethics in the Qur'an is much closed with the term of Khuluq (good nature). It refers to keep behaving a good character in one's personal actions for Allah (S.W.T) or in the actions which involve other people. Abdul Rahim (2013) stated that akhlaq (plural of khuluq) has been determined the human action of life. Such character will produce good human actions and acquire through training and practice. The word "ethics" has its roots in the Greek word "ethos". Ethos refers to the specific values, standards, rules, spirit as well as attitude that people believes and adopt for conducting their lives (Abdul Rahman, 2003). Ethics is also involved the moral philosophy that requires a set of values to serve as a form of reference which entrusted to self-regulated conduct in making decisions about a particular situation beyond the enforcement (Caroll, 1998).

Islam encouraged Muslims to be ethical to others. Goodness can be translated into attitude of does not hurt anybody by either word or deed, forgive those who hurt him or her and forgets the evils done, and returns evil with good. This is because the concept of goodness and morality are becoming center around certain basic beliefs and principles for Muslims to being ethically. As such, Qur'an has been prescribing the concept of goodness such as khayr (goodness), birr (righteousness), 'adl (equilibrium and justice), trust (Amanah), benevolence (Ihsaan) and others. One such concept of goodness in Islam is khayr (goodness). It refers to Muslims doing good and having the right beliefs and actions in the right way such as possessing the values of truthfulness, tolerance, uprightness and others. Islam is the feature of virtue that persuades Muslims to be able to show and behave in the best behaviour towards other people and other creatures if Allah swt, in accordance to Shari'ah principles. Doing khayr (goodness) in Islam is not only required to maintain a good relationship to ultimate creator (habl min Allah) but also it is required to maintain a good relationship to fellow servants (habl min al-nas). This is because behaving khayr (goodness) will benefit people and lead living in harmony with all of creatures of Allah (S.W.T).

In the context of birr (righteousness), it implies the virtues to perform good righteous actions by Muslims. It also expounds in Qur'an to do birr (righteousness) towards all. "Righteousness is not that you turn your faces to the east and the west [in prayer]. But righteous is the one who believes in God, the Last Day, the Angels, the Scripture and the Prophets; who gives his wealth in spite of love for it to kinsfolk, orphans, the poor, the wayfarer, to those who ask and to set slaves free. And (righteous are) those who pray, pay alms, honor their agreements, and are patient in (times of) poverty, ailment and during conflict. Such are the people of truth. And they are the God-Fearing." (Quran 2:177)

Based on the Surah stated above, it is clear that Islam is encouraged Muslims to behave ethically to others by doing birr (righteousness). In Islam, obvious voluntary acts of worship for Allah (S.W.T) are very important, however, based on the Qur'an to be righteous for Allah solely is not enough because Muslims are also important to behave a good deed for other fellow Muslims such as by doing a charity and kindness. Further, Muslims are also encouraged to be steadfast and unshakable in all circumstances such as patient in (times of) poverty, ailment and during conflict is obvious voluntary acts of worship to Allah (S.W.T) in order to get reward and blessing in the hereafter. Moreover, the other concept of goodness in Islam is 'adl (equilibrium and justice), it means "equity and balance", Muslims are encouraged to do justice and fair in the rightful place such as maintaining the right balance between needs of the body, mind and soul. The concept of 'adlit is assumed a moral virtue and an attribute of human personality. As it stated in Qur'an:

"Let not the hatred of a people swerves you away from justice. Be just, for this is closest to righteousness..." (Quran $5: 8)$ 
From the holy Qur'an above, it is be recognized that Islam teaches Muslims to do justice in every aspect in their life as justice is closed to equality in the sense that it creates equilibrium in the distribution of rights and duties to all people, things and times. Another Islamic concept is that trust (Amanah), in Islam the concept amanah is the most basic form of din in mutual relationship for Allah and human 'secular" relation such as to societies. As it is prescribes in Qur'an:

“'Every soul will be (held) in pledge for its deeds". (Qur'an, 74: 38).

In the religious context, Muslims is motivated to fulfil the responsibilities of the trusteeship as a holder of amanah (Trustee of God) on earth and they must bear responsibility for their actions (Abdul Rahman, 2010). The concept of amanah is also related with the term of indebtedness, according to Al-Attas (1978) being indebtedness is not only involved with the responsibility of Muslims to the creator (God) however, the concept of amanah is also being in debt and under obligation naturally with dunya (other people). Thus, whatever that Muslims do it must bear responsibility beyond worldly existence to the life in the hereafter. In addition, Islam is also teaching the concept of benevolence (Ihsaan), it emphasizes on make it the entire Muslims job and work should be excellence. The religion of Islam as the objectives of doing a best practice at work in order to get reward that is commensurate with effort from Allah.

\section{AAOIFI'S Code of Ethics for Accountants}

Moreover, the concepts of goodness based on Shari'ah rules and principles have been used by professional organization such as Accounting and Auditing Organization of Islamic Financial Institutions (AAOIFI) to establish a code of Islamic ethical conduct for accountants in 1998. This code of ethics provides an ethical framework for accountants that help them to become aware and put much attention on the issue of ethics in the professional practice. The purpose of this code of ethics is to motivate and develop the awareness of accountants to comply with such a code for reasons due to religious beliefs and as means of obeying Allah's orders and refraining from things forbidden by Him (AAOIFI, 1998).

Basically, the structure of AAOFI's code of ethical conduct consists of three sections; namely, Shari'ah foundations of ethics for accountants, principles of ethics for accountants and rules of ethical conduct for accountants. The Shari'ah foundations of ethics for accountants depict seven basic foundations that are very fundamentals of ethics in Islam namely, integrity, vicegerency, sincerity, piety, righteousness, Allah-fearing and accountability before Allah. The integrity in Islam requires the accountant and others who are in charge are competent and adequately qualified. As it is confirmed in the Holy Qur'an surah Al-Qasas verse 26: "Truly the best of men to employ is the man who is strong and trustworthy". Thus, integrity means to be true to Allah (S.W.T), for Muslim itself, as well as for societies. The next is vicegerency whereby it is stated in surah Al-Baqarah verse 30: "I will create a vicegerent on earth". Here, it means the human being is only as a vicegerent of God in this world that should observe the commandments and prohibitions of Allah. Mankind also should be accountable for every of their action regarding the way he/she has acquired the wealth as the ultimate owner is Allah.

Sincerity means the accountants should obey Allah in performing their work. It also refers to accountants to be professional as they should not subject themselves to external influences or pressures. The principle is piety, in Islam piety can be defined as taqwa. Fearing Allah in secret and in public is as a way to protect the accountants to behave in accordance with Shari'ah principles and avoiding the prohibitions of Allah. Righteousness refers to the fact that an accountant should perform his occupational and professional duties in the best possible manner. Having academic qualifications, practical experience as well as religious knowledge will help improve righteousness. Allah fearing implies the fact that an accountant in performing his or her occupational and professional duties should act in Allah-fearing ways. The last one is accountability before Allah, it means the accountant should be accountable for his action in this world and in the hereafter

\section{Application of Islamic Ethics for Accountants}

Accounting is a profession that is associated with economic aspects as well as moral aspects (Mayper et al., 2000). In terms of economic content, it means that the information which is provided by accountants can materially affect the lives of their stakeholders as information provided will be used by stakeholders to make decisions e.g. whether or not to invest in a company. In terms of moral dimension, accountants need to behave ethically when they provide and communicate a real and true position of the organization's activities to interested parties (e.g. owners, creditors, government, employees etc.). Without much deliberation on moral issue, it is possible for an accountant to manipulate accounting data. In this sense, behaving ethically and professionally to communicate financial data for decision making are expected traits of accountants.

In terms of educating an individual, Islamic Shari'ah is concerned with the intellectual qualities that are required of Muslims to achieve. It is important to educate Muslims of the importance of the values of being a good human being. In the sense of establishing justice, Islam is concerned with protecting the interest of Muslims and should be able to differentiate between the right and wrong and to act fairly to all. The last benefit is the realization of maslahah to other people. Islamic Shari'ah focuses on the establishment of guidelines to improve the moral judgement of Muslims. In view of the explanation presented above, this paper proposes some suggestions on how Islamic ethics can contribute towards a more ethical accounting practice which are as follows:

\section{Developing Moral Commitment to the Religion}

Accounting practice will be influenced by the behavior of accountants to present and communicate the financial report to the other parties (e.g. shareholders, creditors, societies and others). The corporation of the religious to influence the moral sympathy for others is highly adhering by accountants in order to produce high quality and confidentiality of 
financial information. As such the practice of AAOIFI's code of ethics that are derived from Shari'ah principles should be followed by accountants. The principles of integrity, viceregency, sincerity, piety, righteousness, Allah-fearing and accountability before Allah are the examples that will serve to guide the accounting practice. The fundamental sense to be a good man is very crucial, for a good man will no doubt also be a good citizen, but a good citizen will not necessarily also be a good man. In this sense, Islam emphasizes to be "good" in Islam not only in general aspect such as good in society, good in career, good in education or others, but to be a good man in Islam, Muslim should be good to himself / herself based on Shari'ah principles. This is because Islam differs from western civilization for the purpose of seeking knowledge. A Muslim does not only focus on worldly affairs. Thus, it is the starting point for accountant to bring the Islamic concept as a dominant element in all worldly activities. Islam is very clear in differentiating between beliefs and faith (iman), as well as submission in service (Islam); it is both assent of the heart (qalb) and mind ('aql) confirmed by tongue (lisan) as well as deed and work ('amal) (Al-Attas, 1978). All of these should be in a harmonious relationship between the soul and body, which do not only belief in the heart but also should be deed directly by behaving a good act. Using mind ('aql) in the correct practice and implementation in everyday life is important to work of service to God as being a good man as well as good accountant.

\section{Improvement in Ethics Education System}

There is an increasing attention given to ethics education in accounting. The spread of moral defects of some accountants is a driver to education system improvement. Thorne (2001) suggested that educational practices may be revised to encourage accounting students to increase their tendency to resolve accounting-specific moral dilemmas. Further, there have been empirical studies (Mayper et al., 2000; Thorne, 2001) on ethics and accounting education to examine whether the accounting students use their moral dimension capability in solving accounting-specific moral dilemmas. Again, the results showed that the accounting students do not use their full cognitive moral capability in solving accounting-specific moral dilemmas.

From this perspective, Abdul Rahman (2003) has critiqued the ethical components in the accounting education as insufficient and there is a lack of efforts in humanizing accountants. Further, in order to improve ethics in accounting education, Abdul Rahman (2003) proposes the Islamic legal principle of maslahah as a filtering mechanism by providing three levels of judgement (e.g. essential, complementary and embellishments) as a basis for accountant when resolving ethical conflicts. Daruriyat means any accounting activities or decision that can affect the basic attributes of human life (e.g. self, family, property, intellect) must be protected. In the second level, it is important for an accountant to protect the complementary public interest when the accountant makes any financial decision and accounting disclosures. The third level considers by accountants when they want to achieve embellishments in the financial report such as objectivity, reliability, timeliness and others. Thus, each of them should be considered by preceding the most important things based on the need and condition.

\section{Enforcement of Code of Ethics}

The code of ethics is expected to guide the accountants' individual tendency to act in a moral way. Nevertheless, the codes of ethics as a source of reference do not assist in solving the moral problems and does not much influence the behavior of accountants (Bakar et al., 2002). Uniform enforcement of code of ethics is important towards a more ethical accounting practice (Moriarity, 2000). This will lead to the quality and integrity of financial reports as the accountant will follow the code of ethics as guidelines when resolving ethical conflicts. For example, Bakar et al. (2002) examined the role of code of ethics in influencing the behavior of accountants when solving ethical conflicts. The study revealed that code of ethics has no significant influence on the behavior of accountants. Most of the accountants use their experience, level of responsibility and education as the basis to guide them how to solve conflicts and dilemma in decision making process.

\section{CONCLUSION}

Accounting is considered as a moral discipline as the information produces by accountants include the economic as well as moral content (Mayper et al., 2000). As accountant has the responsibility to communicate data not only for organization that they served but also for society at large. In Islam the concept of taklif (accountability) is very important, it means everyone is accountable for every of his action on the Day of Judgment. According to Al-Attas (1978) Islam is the religion that ultimately denotes the faith, belief, practices and teachings adhered to by Muslims as their objectives of religion. From this point of view, the accountants in Islam is motivated to provide the excellent job because as a holder of amanah in searching of bounties of Allah. Thus, the effort for manifesting some of Islamic guidelines for accountants as a source to conduct their behavior and compliance with Islamic principles is highly needed. Islamic ethics as a reference for accountants to provide the excellent work to fulfil Shari'ah requirements and to provide the required information demanded by society such as by doing khayr (goodness), birr (righteousness), 'adl (equilibrium and justice), trust (Amanah), benevolence (Ihsaan) and others. The understanding and application of Islamic ethics contribute towards a more ethical accounting practice by following some stages; first, it starts by developing morality commitment to the religion, second, improvement ethics education system, and the last one is enforcement of Code of Ethics. 


\section{REFERENCES}

AAOIFI (1998). Code of ethics for accountants and auditors of Islamic financial institutions, Bahrain.

Abdul Rahim, A. (2013). Understanding Islamic ethics and its significance on character building.

Abdul Rahman, A. R. (2003). Ethics in accounting education: Contribution of the Islamic Principle of Maslahah. IIUM Journal of Economics and Management, 11(1), 31-49.

Abdul Rahman, A. R. (2010). An introduction Islamic accounting theeory and practice. Kuala Lumpur: Centre for Research and Training.

Akyel, N. (2012). Forensic accounting training: A proposal for turkey. Procedia-Social and Behavioral Sciences, 55, 77-86.

Alanzi, K. A., \& Alfraih, M. M. (2017). Does accumulated knowledge impact academic performance in cost accounting? Journal of International Education in Business, 10(01), 2-11.

Al-Attas, S. M. A. (1978). Islam and Secularism, ABIM Malaysia. (Chapter III-Islam: The concept of religion and the foundation of ethics and morality).

Al-Faruqi, I. R. (1986). Al-Tawhid: Its implications for thought and life, International Institute of Islamic Thought (IIIT), USA. (Chapter 1: The Essence of Religious Experience \& Chapter 2: The Quintessence of Islam).

Bakar, M. A., Saat, M. M. \& Abdul Majid, A. (2002). Ethics in the accounting profession in Malaysia, Proceeding AAAA conference, Nagoya: Japan.

Carroll, R. (1998). A model for ethical education in accounting in Gowthorpe, C \& Blake, J., Ethical Issues in Accounting (Ed.), London: Routledge.

Johnnie, P. B. (1993). Formal education: A paradigm for human resource development in organizations. International Journal of Educational Management, 7(5), 4-8.

Mayper, A. G., Hoops, W., Pavur, R. \& Merino, B. D. (2000). Accounting: A moral discipline? Proceeding Interdisciplinary Perspective of Accounting Conference, Manchester: UK

McPhail, K. (2001). The other objectives of ethics educations: Re-Humanising the accountancy profession - A study of ethics education in Law, Engineering, Medicine and Accounting. Journal of Business Ethics, 34, Kluwer, Netherlands.

Moriarty, S. (2000). Trends in ethical sanctions within the accounting profession. Accounting Horizons, 14(4).

Thorne, L. (2001). Refocusing ethics education in accounting: An examination of accounting students' tendency to use their cognitive moral capability. Journal of Accounting Education, 19, Elsevier. 